Article

\title{
Antibody Response to mRNA Vaccines against SARS-CoV-2 with Chronic Kidney Disease, Hemodialysis, and after Kidney Transplantation
}

\author{
Lukas Buchwinkler, Claire Anne Solagna, Janosch Messner, Markus Pirklbauer (D, Michael Rudnicki (D, \\ Gert Mayer and Julia Kerschbaum *(D)
}

Citation: Buchwinkler, L.; Solagna, C.A.; Messner, J.; Pirklbauer, M.;

Rudnicki, M.; Mayer, G.;

Kerschbaum, J. Antibody Response to mRNA Vaccines against SARS-CoV-2 with Chronic Kidney Disease, Hemodialysis, and after

Kidney Transplantation. J. Clin. Med. 2022, 11, 148. https://doi.org/ 10.3390/jcm11010148

Academic Editor: Giorgina

Barbara Piccoli

Received: 24 November 2021

Accepted: 26 December 2021

Published: 28 December 2021

Publisher's Note: MDPI stays neutral with regard to jurisdictional claims in published maps and institutional affiliations.

Copyright: (c) 2021 by the authors. Licensee MDPI, Basel, Switzerland. This article is an open access article distributed under the terms and conditions of the Creative Commons Attribution (CC BY) license (https:/ / creativecommons.org/licenses/by/ $4.0 /)$.

\author{
Department of Internal Medicine IV-Nephrology and Hypertension, Medical University Innsbruck, \\ Anichstrasse 35, 6020 Innsbruck, Austria; lukas.buchwinkler@i-med.ac.at (L.B.); \\ claire.solagna@student.i-med.ac.at (C.A.S.); janosch.messner@student.i-med.ac.at (J.M.); \\ markus.pirklbauer@i-med.ac.at (M.P.); michael.rudnicki@i-med.ac.at (M.R.); gert.mayer@i-med.ac.at (G.M.) \\ * Correspondence: julia.kerschbaum@i-med.ac.at
}

\begin{abstract}
Most trials on mRNA vaccines against SARS-CoV-2 did not include patients with chronic kidney disease (CKD), hemodialysis (HD) patients, or kidney transplant recipients (KTR). However, those patients have a higher risk for a severe course of COVID-19 disease and mortality. Available literature has demonstrated a reduced efficacy of mRNA vaccines in HD patients and KTR, while data on CKD patients is scarce. Additionally, factors associated with non-response are poorly understood and not well characterized. We assessed antibody (AB) response ( $n=582,160$ CKD patients, 206 patients on HD, $216 \mathrm{KTR}$ ) after the administration of two doses of a mRNA-vaccine with either BNT162b2 or mRNA-1273. AB measurements were carried out after a median of 91 days after first vaccinations, demonstrating non-response in $12.5 \%$ of CKD patients, $12.1 \%$ of HD patients, and $50 \%$ of KTR. AB titers were significantly higher in CKD patients than in HD patients or KTR. Factors associated with non-response were treated with rituximab in CKD patients, the use of calcineurin inhibitors in HD patients and older age, and the use of BNT162b2, mycophenolic acid, or glucocorticoids and lower hemoglobin levels in KTR. This study contributes to the understanding of the extent and conditions that predispose for non-response in patients with impaired kidney function.
\end{abstract}

Keywords: SARS-CoV-2; COVID-19; mRNA vaccines; kidney transplantation; hemodialysis; chronic kidney disease

\section{Introduction}

To combat the ongoing COVID-19 pandemic, significant effort has been undertaken to develop highly effective and safe vaccines against SARS-CoV-2 (severe acute respiratory syndrome coronavirus 2). Two of the most promising vaccines are BNT162b2 by Pfizer and mRNA-1273 by Moderna. However, the respective authorization trials as well as most follow-up trials on these mRNA vaccines did not include patients with chronic kidney disease (CKD), on hemodialysis (HD), or after kidney transplantation (KT). Moreover, immunosuppressive treatment was an exclusion criterion in the original registration studies [1,2]. Several publications have already indicated a reduced humoral immune response in HD [3-5] and kidney transplant recipients (KTR) [6-8], while data in CKD patients with or without immunosuppressive treatment is scarce. Factors/conditions discussed to predispose non-response and a severe COVID-19 course in these patients are advanced age, comorbidities, the uremic environment in HD, and immunosuppressive medication in KTR. Factors that are associated with non-response in the existing literature include age $[9,10]$, diabetes [11], lower hemoglobin [9], lower eGFR (per $\mathrm{mL} / \mathrm{min} / 1.73 \mathrm{~m}^{2}$ ) [12], longer HD vintage [13], BNT162b2 instead of mRNA-1273 [14-17], treatment with antimetabolites [18] or belatacept $[19,20]$, treatment with rituximab [21] or high dose cortisone in the last year [9], 
and triple immunosuppression (calcineurin inhibitor plus antimetabolite plus steroid) [9]. The extent and impact of the abovementioned factors are poorly understood, and possible mitigation strategies are lacking.

Since mortality in SARS-CoV-2-infected kidney transplant recipients [22], hemodialysis patients [23], and CKD patients [24] is high, further understanding of the efficacy of the SARS-CoV-2 vaccination and risk factors for non-response in this highly vulnerable population is urgently needed. Safe and effective vaccination strategies remain especially important due to the fact that, as of date, effective treatments for severe COVID-19 disease are rarely available. Additionally, most of these patients have difficulties to socially distance due to either needing regular hemodialysis, medical appointments, or care through relatives or nursing personnel.

\section{Materials and Methods}

Between February and April 2021, CKD patients, HD patients, and KT recipients received two doses of mRNA-vaccination based on the recommendations of the Austrian National Advisory Committee on immunization practices. Patients were treated in Tyrolean dialysis centers or by the Department of Internal Medicine IV at the University Hospital Innsbuck. Data were analyzed retrospectively; inclusion in this study did not play any role in immunization practices. Routine laboratory parameters and clinical data were assessed in May and June 2021 through electronic patient records.

Antibody (AB) titers were measured by Abbott SARS-CoV-2 IgG II Quant Assay in $40 \%$ of each group and by Liaison ${ }^{\circledR}$ SARS-CoV-2 S1/S2 IgG in $60 \%$ of each group based on availability in our laboratory between January and August 2021. Limits for nonresponse were $<7 \mathrm{BAU} / \mathrm{mL}$ and $<13 \mathrm{AU} / \mathrm{mL}$, respectively, as defined by the manufacturer. Measurements with the Liaison assay were carried out and analyzed before the conversion of the assay to BAU/mL, hence the unit $\mathrm{AU} / \mathrm{mL}$ is used (the now defined cut-off of 33.8 $\mathrm{BAU} / \mathrm{mL}$ is equivalent to $13 \mathrm{AU} / \mathrm{mL}$, conversion factor 2.6).

Inclusion criteria comprised either CKD (predominantly CKD stage IV and V), HD or living with a functioning kidney graft as underlying condition, completed prime-booster vaccination with a mRNA vaccine approximately 4 weeks apart, and an available measurement of $A B$ titers with at least one of the above-mentioned assays 60 to 120 days after first vaccine dose. Exclusion criteria included age under 18 years at the time of first vaccination and a history of PCR-proven SARS-CoV-2 infection or the detection of nucleocapsid AB.

BNT162b2 was used in 58\% of CKD patients, in $96 \%$ of HD patients, and in $49 \%$ of KTR; the remainder received mRNA-1273. Both doses were administered approximately 4 weeks apart (median 28 days, $25 \%$ and $75 \%$ percentiles were 21 and 29 days). AB measurement was carried out after a median of 91 days after the first vaccination.

Statistical analysis was performed with IBM SPSS Statistics. Non-parametric tests were used for the comparison of continuous data, and logistic regression served for assessment of risk factors for non-response. All factors showing a univariate association with a $p$-value $<0.100$ were entered in the final multivariate model.

This analysis was approved by the Institutional Review Board of the Medical University Innsbruck (ECS 1280/2021).

\section{Results}

The initial cohort consisted of 871 patients with either CKD, treatment with HD or after kidney transplantation. Sixty-two patients were excluded due to a history of SARS-CoV-2 infection before the first or the second dose, and 17 patients were excluded due to nucleocapsid $\mathrm{AB}$ detection before the first or second dose without a clinically apparent history of infection. Nineteen patients had no second dose of vaccination. From the remaining 773 patients, in 191 patients, antibodies were not taken between 60 to 120 days after the first vaccination. Hence, in the final cohort, 582 patients were included: 160 patients with CKD, 206 patients on HD, and 216 patients after kidney transplantation. Table 1 displays baseline characteristics of the final cohort. 
Table 1. Data is displayed as median, $25 \%$, and $75 \%$ percentiles. Numeric data is displayed as number of participants $(n)$ and percentage (\%) where appropriate (sums do not add up to $100 \%$ due to rounding).

\begin{tabular}{|c|c|c|c|}
\hline & CKD $(n=160)$ & HD $(n=206)$ & KTR $(n=216)$ \\
\hline Age (years) & $63.1(53.5-74.5)$ & $69.5(57.5-78.6)$ & $59.9(50.7-68.5)$ \\
\hline Female $(n, \%)$ & $66(41)$ & $66(32)$ & $69(32)$ \\
\hline BMI $\left(\mathrm{kg} / \mathrm{m}^{2}\right)$ & $25.6(23.3-29.3)$ & $24.9(22.2-28.4)$ & $24.8(21.7-27.8)$ \\
\hline \multicolumn{4}{|l|}{ Primary renal disease $(n, \%)$} \\
\hline Diabetic nephropathy & $14(9)$ & $45(22)$ & $28(13)$ \\
\hline Glomerulonephritis & $64(40)$ & $35(17)$ & $71(33)$ \\
\hline Other & $49(31)$ & $55(27)$ & $77(36)$ \\
\hline Unknown & $3(2)$ & $23(11)$ & $11(5)$ \\
\hline Vascular nephropathy & $30(19)$ & $48(23)$ & $29(13)$ \\
\hline \multicolumn{4}{|l|}{ Comorbidities $(n)$} \\
\hline Cardiovascular disease & 45 & 98 & 92 \\
\hline Cerebrovascular disease & 16 & 33 & 34 \\
\hline Active or former malignancy & 13 & 35 & 53 \\
\hline Diabetes mellitus & 36 & 77 & 79 \\
\hline \multicolumn{4}{|l|}{ Comedication $(n, \%)$} \\
\hline Treatment with RAAS inhibitors & $83(52)$ & $62(30)$ & $93(43)$ \\
\hline $\begin{array}{l}\text { High-dose glucocorticoid treatment } \\
\text { during last year }(\geq 1 \mathrm{mg} / \mathrm{kg})\end{array}$ & $6(4)$ & $4(2)$ & $16(7)$ \\
\hline Tacrolimus & - & $7(3)$ & $152(70)$ \\
\hline Cyclosporine A & - & $1(0.5)$ & $38(18)$ \\
\hline Azathioprine & - & 0 & $33(15)$ \\
\hline Mycophenolic acid & - & $2(1)$ & $148(69)$ \\
\hline Belatacept & - & 0 & $14(6)$ \\
\hline Glucocorticoids & - & $8(4)$ & $178(82)$ \\
\hline mTor inhibitors & - & 0 & $11(5)$ \\
\hline Rituximab & $30(19)$ & - & - \\
\hline $\begin{array}{l}\text { Time between 1st vaccination and } \\
\text { rituximab (days) }\end{array}$ & $242(127-324)$ & $2(1-4)$ & $2(1-3)$ \\
\hline Classes of antihypertensive drugs $(n)$ & $2(1-3)$ & & \\
\hline \multicolumn{4}{|l|}{ Laboratory values } \\
\hline Albumin (g/dL) & $4.0(3.7-4.3)$ & $3.8(3.4-4.1)$ & \\
\hline Hemoglobin $(\mathrm{g} / \mathrm{dL})$ & $132(117-141)$ & $111(105-120)$ & $4.1(3.9-4.4)$ \\
\hline C-reactive protein $(\mathrm{mg} / \mathrm{dL})$ & $0.20(0.09-0.46)$ & $0.33(0.16-0.95)$ & $134(122-146)$ \\
\hline eGFR $\left(\mathrm{mL} / \mathrm{min} / 1.73 \mathrm{~m}^{2}\right)$ & $29.9(19.8-49.9)$ & - & $0.19(0.08-0.40)$ \\
\hline
\end{tabular}

The median age was 63.1, 69.5, and 59.9 years, respectively, in CKD patients, HD patients, and KTR. The median eGFR was $29.9 \mathrm{~mL} / \mathrm{min} / 1.73 \mathrm{~m}^{2}$ in CKD patients and $49.2 \mathrm{~mL} / \mathrm{min} / 1.73 \mathrm{~m}^{2}$ in KTR. Details on immunosuppressive treatment and comorbidities are also given in Table 1 . The median time between the first vaccination and $\mathrm{AB}$ measurement was 91 days in all groups. Table 2 shows the type of vaccine used and the types and 
results of antibody measurement. Rates of non-response were $12.5 \%, 12.1 \%$, and $50.0 \%$ in CKD patients, HD patients, and KTR.

Table 2. Type of vaccine and antibody measurement in CKD and HD patients, and KTR. Continuous data is displayed as median, $25 \%$, and $75 \%$ percentiles. Numeric data is displayed as number of participants $(n)$ and percentage (\%) where appropriate (sums do not add up to $100 \%$ due to rounding).

\begin{tabular}{llll}
\hline & CKD $(n=160)$ & HD $(n=206)$ & KTR $(n=216)$ \\
\hline $\begin{array}{l}\text { Type of antibody measurement } \\
(n, \%)\end{array}$ & & & \\
$\begin{array}{l}\text { Abbott SARS-CoV-2 IgG II Quant } \\
\text { Assay }\end{array}$ & $65(40.6)$ & $84(40.8)$ & $88(40.7)$ \\
$\begin{array}{l}\text { Liaison }{ }^{\circledR} \text { SARS-CoV-2 S1/S2 IgG } \\
\text { Vaccine }(n, \%)\end{array}$ & $95(59.4)$ & $122(59.2)$ & $128(59.3)$ \\
$\begin{array}{l}\text { BNT162b2 } \\
\text { mRNA-1273 }\end{array}$ & $93(58.1)$ & $198(96.1)$ & $106(49.1)$ \\
$\begin{array}{l}\text { Results of antibody measurement } \\
\text { Abbott SARS-CoV-2 IgG II Quant }\end{array}$ & $67(41.9)$ & $8(3.9)$ & $110(50.9)$ \\
$\begin{array}{l}\text { Assay } \\
\text { titer (BAU/mL) }\end{array}$ & $230.3(48.3-497.6)$ & $151.6(47.7-458.4)$ & $4.75(3.0-30.2)$ \\
$\begin{array}{l}\text { Liaison }{ }^{\circledR} \text { SARS-CoV-2 S1/S2 IgG } \\
\text { titer (AU /mL) }\end{array}$ & $602.0(252.5-800.0)$ & $121.5(32.0-293.0)$ & $10.3(1.9-74.3)$ \\
$\begin{array}{l}\text { Non-response }(n, \%) \\
\text { Time between 1st vaccination and }\end{array}$ & $20(12.5)$ & $25(12.1)$ & $108(50.0)$ \\
AB measurement (days) & $91(90-96)$ & $91(88-94)$ & $91(90-95)$ \\
\hline
\end{tabular}

Levels of antibody titers were significantly higher in CKD patients (Abbott: 230.3 BAU/mL [48.3-497.6]; Liaison: 602.0 AU/mL [252.5-800.0]) than in HD patients (Abbott: 151.6 BAU/mL [47.7-458.4]; Liaison: $121.5 \mathrm{AU} / \mathrm{mL}$ [32.0-293.0]); $(p<0.001)$ and in KTR (Abbott: 4.75 BAU/mL [3.0-30.2]; Liaison: 10.3 AU/mL [1.9-74.3]); (all $p<0.001$, Figure 1).

In a multivariate analysis, risk factors for non-response were examined. In CKD, a significant risk factor for non-response was treatment with rituximab (OR 27.2, 95\% CI $5.12-144.63, p<0.001$ ) before vaccination (Table 3). The rate of non-response was 53.3\% in CKD patients treated with rituximab $(n=30)$ versus $3.1 \%$ in those without rituximab treatment $(n=130)$. Longer temporal distance of rituximab application to first vaccination significantly reduced the risk for non-response (OR 0.98, 0.96-1.00, $p=0.020$ per day).

Table 3. Multivariate analysis of risk factors for non-response in CKD patients. OR odds ratio, CI confidence interval.

\begin{tabular}{lll}
\hline & OR (95\% CI) & $p$-Value \\
\hline Glomerulonephritis & $1.53(0.24-9.75)$ & 0.651 \\
\hline Rituximab treatment & $27.20(5.12-144.63)$ & $<0.001$ \\
\hline Days between 1st vaccination and Rituximab (per day) & $0.98(0.96-1.00)$ & 0.020 \\
\hline
\end{tabular}

In HD patients with renal transplant in situ $(n=39)$, the use of calcineurin inhibitors was significantly associated with non-response (OR 14.85, 2.68-82.43, $p=0.002)$; no other risk factors could be identified in HD patients (Table 4). 
(a)

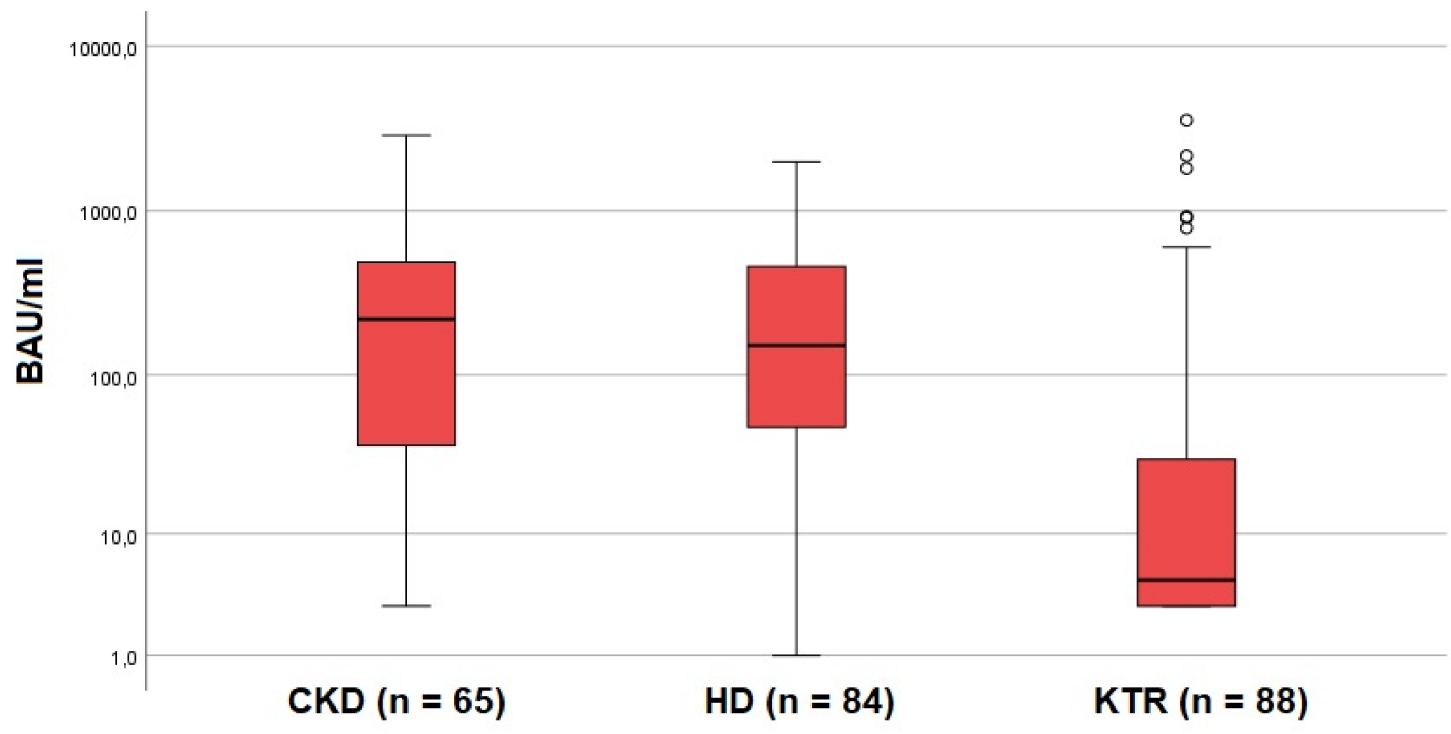

(b)

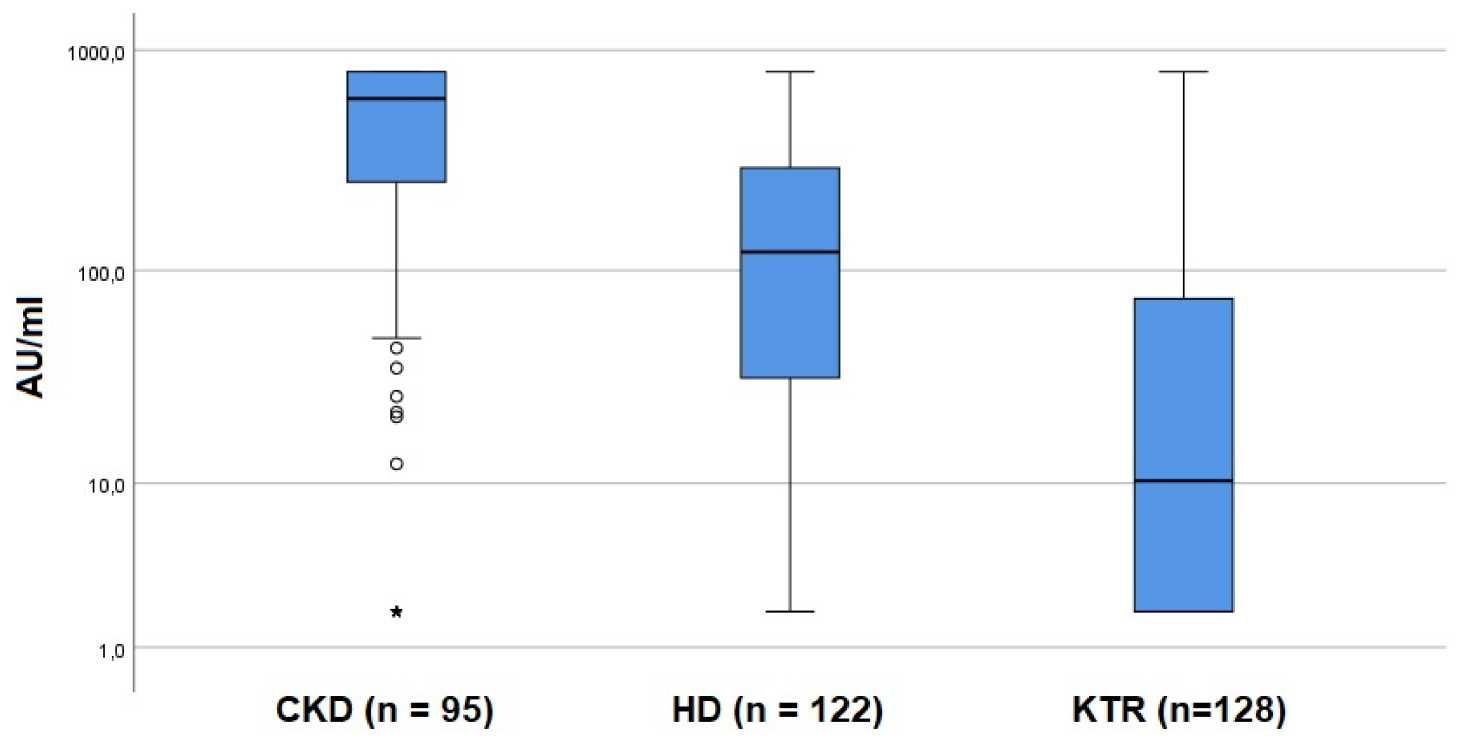

Figure 1. (a,b): Levels of antibody titers in CKD patients, HD patients, and KTR. (a) shows the results of the Abbott SARS-CoV-2 IgG II Quant Assay test (median, 25, and 75\% percentile for CKD: 230.3 (48.3-497.6), for HD: 151.6 (47.7-458.4), for KTR: 4.8 (3.0-30.2); (b) shows the results of the Liaison ${ }^{\circledR}$ SARS-CoV-2 S1/S2 IgG test (median, 25, and 75\% percentile for CKD: 602.0 (252.5-800.0), for HD: 121.5 (32.0-293.0), for KTR: 10.3 (1.9-74.3). Logarithmic scale. Circles represent statistical outliers between 1.5 to 3.0 times of the interquartile range (IQR), asterisks represent statistical outliers more than 3 times of the IQR. 
Table 4. Multivariate analysis of risk factors for non-response in HD patients. OR odds ratio, CI confidence interval.

\begin{tabular}{lll}
\hline & OR (95\% CI) & $p$-Value \\
\hline Glomerulonephritis & $2.87(0.95-8.70)$ & 0.062 \\
\hline High-dose glucocorticoid treatment during last year $(\geq 1 \mathrm{mg} / \mathrm{kg})$ & $6.36(0.67-60.44)$ & 0.107 \\
\hline Treatment with tacrolimus or cyclosporine A & $14.85(2.68-82.43)$ & 0.002 \\
\hline Glucocorticoids & $1.90(0.25-14.49)$ & 0.537 \\
\hline Hemoglobin $($ per g/dL) & $0.97(0.95-1.01)$ & 0.098 \\
\hline
\end{tabular}

In KTR, higher age (OR 1.06, 1.03-1.09, $p<0.001$ per year) was significantly associated with non-response (Table 5). The use of mycophenolic acid (OR 6.61, 2.31-18.86, $p<0.001$ ) or glucocorticoids (OR 4.95, 1.48-16.57, $p=0.010$ ) was also significantly associated with non-response, whereas vaccination with mRNA-1273 (OR 0.41, $0.20-0.83, p=0.014$ ) and higher levels of hemoglobin (OR 0.97, $0.95-0.99, p<0.001$ per $\mathrm{g} / \mathrm{L}$ significantly reduced the risk for non-response. Treatment with belatacept was not significantly associated with non-response, possibly due to a low patient number $(n=14)$.

Table 5. Multivariate analysis of risk factors for non-response in KTR. OR odds ratio, CI confidence interval, KT kidney transplantation.

\begin{tabular}{lll}
\hline & OR (95\% CI) & $p$-Value \\
\hline Age (per year) & $1.06(1.03-1.09)$ & $<0.001$ \\
\hline Type of vaccination & Ref. & - \\
\hline BNT162b2 & $0.41(0.20-0.83)$ & 0.014 \\
\hline mRNA-1273 & $3.11(0.99-9.76)$ & 0.052 \\
\hline Cerebrovascular disease & $1.22(0.47-3.18)$ & 0.681 \\
\hline CMV reactivation during the last 6 months & & \\
\hline Basis of immunosuppression & Ref. & - \\
\hline Antimetabolite and/or steroids & $0.89(0.06-14.23)$ & 0.934 \\
\hline Cyclosporine A & $1.59(0.11-22.38)$ & 0.730 \\
\hline Tacrolimus & $0.31(0.01-10.42)$ & 0.512 \\
\hline mTOR inhibitors & $11.01(0.45-269.68)$ & 0.142 \\
\hline Belatacept & & \\
\hline Antimetabolites & Ref. & - \\
\hline No antimetabolites & $0.73(0.18-2.92)$ & 0.652 \\
\hline Azathioprine & $6.61(2.31-18.86)$ & $<0.001$ \\
\hline Mycophenolic acid & $4.95(1.48-16.57)$ & 0.010 \\
\hline Glucocorticoids & $0.97(0.95-0.99)$ & $<0.001$ \\
\hline Hemoglobin (per g/dL) & $0.99(0.94-1.04)$ & 0.660 \\
\hline Time since last KT (per year) & & \\
\hline
\end{tabular}

Presence of diabetes or the underlying primary renal disease (diabetic nephropathy, vascular/hypertensive nephropathy, glomerulonephritis, other, unknown) did not predict non-response in any of the groups. In addition, the presence of cardiovascular or cerebrovascular disease were not associated with non-response. Further non-significant factors were treatment with RAAS inhibitors and the number of classes of antihypertensive drugs. 


\section{Discussion}

This is one of the first studies showing a direct comparison of SARS-CoV-2 antibody titers in CKD patients with and without immunosuppressive treatment, HD patients, and KTR. We found levels of antibody titers to be significantly higher in CKD patients than in HD patients and KTR. Interestingly, primary non-response in CKD and HD patients was approximately the same (12.5\% vs. $12.1 \%)$. The non-response rate in HD is in line with recent literature [25]. It has been demonstrated that immunosuppressive medication after transplantation impairs immune response to (not only SARS-CoV-2) vaccines [26] and influences immunization practices of listed HD patients [27]. Our data also suggests a possible advantage of vaccination before the initiation of renal replacement therapy (RRT).

The low AB titers in HD patients and KTR might indicate the need for a scheduled booster regimen to enhance immune response in those patients. In particular, the very low titers in KTR are alarming, not only regarding the potential of vaccines to protect against COVID-19 disease, but also the longevity of the supposed protection. Several trials have already reported on immune responses to a third vaccine dose in KTR non-responders [28-30] and weak responders [31], as well as HD patients [32,33]. Approximately 50\% of KTR developed a positive $\mathrm{AB}$ response after a third dose. A fourth dose seems to have a similar efficacy [34]. This raises the question of the efficiency of available vaccines (or vaccination strategies) to grant adequate protection from COVID-19 in KTR. In the case of continuous non-/or very low-response, basic hygiene measures, social distancing, and especially a high vaccination coverage of care providers, relatives, and the general population remain highly important. To the best of our knowledge, no systematic analysis of efficacy of a third vaccine dose in CKD patients exists.

Recent publications demonstrated a $100 \%$ percent development of AB after vaccination in CKD patients $[35,36]$. Our finding of a response rate of $87.5 \%$ can be partially explained by the fact that, in contrast to these studies, we included CKD patients with immunosuppressive medication. In our cohort, 19\% of CKD patients received rituximab treatment, while six patients received a high dose glucocorticoid treatment $(>1 \mathrm{mg} / \mathrm{kg}$ body weight) during the last year.

A limitation of our study is the fact that we did not assess cellular immune responses. While it is reasonable to assume that immunosuppressive medication impairs cellular immune response to a similar extent than humoral response (with the exception of rituximab), some studies exist that demonstrated a significant T-cell immunity in cases of humoral non-response $[37,38]$. The extent to which S1-AB titer correlates with protection against infection and severe COVID-19 courses is incompletely understood. An interesting point was raised in recent publications: while the development of positive AB titers seems to correlate reasonably well with neutralizing antibodies [39] and neutralizing capacity of patient plasma [40], 10\% of seropositive KTRs did not develop neutralizing capacity [39]. Comparison and interpretation of cellular assays is difficult due to the heterogeneity of employed analyses. While the analysis of S1-AB assays might not be able to inform on the whole immunologic picture, an inexpensive tool, easy to deploy and compare, is needed to combat the ongoing pandemic and inform on sufficient or inadequate protection. The lack of follow-up is a limitation of our study; "real life" data on break-through infections and COVID-19 infection courses of vaccinated immunosuppressed patients are urgently needed.

Furthermore, specific immunosuppressive agents (such as rituximab in CKD patients, calcineurin inhibitors in HD patients with transplant in situ, and mycophenolic acid and glucocorticoids in KTR) might influence immune response, suggesting a possible need for a change in immunosuppressive therapy ahead of vaccination. While changes to immunosuppression in KTR should be handled with caution, in HD patients temporarily pausing immunosuppressive medication prescribed to preserve residual kidney function seems feasible, though it is unclear if pausing immunosuppression is sufficient to restore an adequate vaccine response. Our data also suggests aiming for a temporal distance of vaccination to the last rituximab administration in CKD patients, which is in line with current 
literature [41]. While induction treatment with rituximab, for example in ANCA-associated vasculitis, usually cannot be delayed, postponing COVID-19 vaccination until the reconstitution of CD19+ B-cells, a transient switch to other immunosuppressive treatments (such as azathioprine) or a delay of rituximab treatment in stable patients may be warranted [42]. In any case, a careful benefit-risk analysis by the providing physician is needed in such instances.

In line with the available literature, our data favours the usage of mRNA-1273 over BNT162b2 in KTR [16,17] as well as HD [14,15] to ensure optimal response. As of to date, no such recommendation has found entry in international, national or scientific guidelines on vaccination strategies.

The data of our study were collected at a time where SARS-CoV-2 variants of concern (Delta, Omicron) did not play a major epidemiological role in Austria.

In general, the vaccination of household members and other close contacts is essential and has been shown to reduce the transmission rate [43].

In summary, our study expands the knowledge of AB response to mRNA-based SARSCoV-2 vaccinations in different groups of patients with impaired kidney function. Patients with CKD had a significantly better immune response than patients on HD or KTR, while still over $10 \%$ of CKD patients did not mount a detectable immune response. Clinical studies on antibody levels as well as cellular immune responses, duration of protection, and break through infections in those patients are clearly needed to inform on future immunization strategies and optimal treatment.

Author Contributions: Conceptualization, L.B. and J.K.; methodology, J.K.; software, C.A.S., J.M. and J.K.; validation, C.A.S. and J.K.; formal analysis, J.K.; investigation, L.B., M.P., M.R. and J.K.; resources, M.P., M.R. and G.M.; data curation, C.A.S., J.M. and J.K.; writing-original draft preparation, L.B. and J.K.; writing-review and editing, L.B., C.A.S., J.M., M.P., M.R., G.M. and J.K.; supervision, G.M.; project administration, L.B. and J.K. All authors have read and agreed to the published version of the manuscript.

Funding: This research received no external funding.

Institutional Review Board Statement: The study was conducted according to the guidelines of the Declaration of Helsinki and approved by the Institutional Review Board of the Medical University Innsbruck (ECS 1280/2021, 31 August 2021).

Informed Consent Statement: Patient consent was waived due to the retrospective design of the study collecting data on routine measurements.

Data Availability Statement: The data presented in this study are available on request from the corresponding author. The data are not publicly available due to data protection.

Acknowledgments: We want to thank all participating centers in Tyrol, especially Hermann Kathrein, Matthias Post, Florian Reinstaller, Regina Schlacher, Angelika Senn, Karin Erhart, Eva Tamerl, and Christine Wohlgemuth.

Conflicts of Interest: The authors declare no conflict of interest.

\section{References}

1. Polack, F.P.; Thomas, S.J.; Kitchin, N.; Absalon, J.; Gurtman, A.; Lockhart, S.; Perez, J.L.; Pérez Marc, G.; Moreira, E.D.; Zerbini, C.; et al. Safety and Efficacy of the BNT162b2 mRNA Covid-19 Vaccine. N. Engl. J. Med. 2020, 383, 2603-2615. [CrossRef]

2. Baden, L.R.; El Sahly, H.M.; Essink, B.; Kotloff, K.; Frey, S.; Novak, R.; Diemert, D.; Spector, S.A.; Rouphael, N.; Creech, C.B.; et al. Efficacy and Safety of the mRNA-1273 SARS-CoV-2 Vaccine. N. Engl. J. Med. 2021, 384, 403-416. [CrossRef]

3. Yanay, N.B.; Freiman, S.; Shapira, M.; Wishahi, S.; Hamze, M.; Elhaj, M.; Zaher, M.; Armaly, Z. Experience with SARS-CoV-2 BNT162b2 mRNA vaccine in dialysis patients. Kidney Int. 2021, 99, 1496-1498. [CrossRef]

4. Grupper, A.; Sharon, N.; Finn, T.; Cohen, R.; Israel, M.; Agbaria, A.; Rechavi, Y.; Schwartz, I.F.; Schwartz, D.; Lellouch, Y.; et al. Humoral Response to the Pfizer BNT162b2 Vaccine in Patients Undergoing Maintenance Hemodialysis. Clin. J. Am. Soc. Nephrol. 2021, 16, 1037-1042. [CrossRef]

5. Billany, R.E.; Selvaskandan, H.; Adenwalla, S.F.; Hull, K.L.; March, D.S.; Burton, J.O.; Bishop, N.C.; Carr, E.J.; Beale, R.; Tang, J.W.; et al. Seroprevalence of antibody to $\mathrm{S} 1$ spike protein following vaccination against COVID-19 in patients receiving hemodialysis: A call to arms. Kidney Int. 2021, 99, 1492-1494. [CrossRef] 
6. Boyarsky, B.J.; Werbel, W.A.; Avery, R.K.; Tobian, A.A.R.; Massie, A.B.; Segev, D.L.; Garonzik-Wang, J.M. Antibody Response to 2-Dose SARS-CoV-2 mRNA Vaccine Series in Solid Organ Transplant Recipients. JAMA 2021, 325, 2204-2206. [CrossRef]

7. Benotmane, I.; Gautier-Vargas, G.; Cognard, N.; Olagne, J.; Heibel, F.; Braun-Parvez, L.; Martzloff, J.; Perrin, P.; Moulin, B.; Fafi-Kremer, S.; et al. Low immunization rates among kidney transplant recipients who received 2 doses of the mRNA-1273 SARS-CoV-2 vaccine. Kidney Int. 2021, 99, 1498-1500. [CrossRef]

8. Korth, J.; Jahn, M.; Dorsch, O.; Anastasiou, O.E.; Sorge-Hädicke, B.; Eisenberger, U.; Gaeckler, A.; Dittmer, U.; Witzke, O.; Wilde, B.; et al. Impaired Humoral Response in Renal Transplant Recipients to SARS-CoV-2 Vaccination with BNT162b2 (Pfizer-BioNTech) Viruses 2021, 13, 756. [CrossRef]

9. Grupper, A.; Rabinowich, L.; Schwartz, D.; Schwartz, I.F.; Ben-Yehoyada, M.; Shashar, M.; Katchman, E.; Halperin, T.; Turner, D.; Goykhman, Y.; et al. Reduced humoral response to mRNA SARS-CoV-2 BNT162b2 vaccine in kidney transplant recipients without prior exposure to the virus. Am. J. Transplant. 2021, 21, 2719-2726. [CrossRef]

10. Attias, P.; Sakhi, H.; Rieu, P.; Soorkia, A.; Assayag, D.; Bouhroum, S.; Nizard, P.; El Karoui, K. Antibody response to the BNT162b2 vaccine in maintenance hemodialysis patients. Kidney Int. 2021, 99, 1490-1492. [CrossRef]

11. Cucchiari, D.; Egri, N.; Bodro, M.; Herrera, S.; Del Risco-Zevallos, J.; Casals-Urquiza, J.; Cofan, F.; Moreno, A.; Rovira, J.; Banon-Maneus, E.; et al. Cellular and humoral response after MRNA-1273 SARS-CoV-2 vaccine in kidney transplant recipients. Am. J. Transplant. 2021, 21, 2727-2739. [CrossRef]

12. Rozen-Zvi, B.; Yahav, D.; Agur, T.; Zingerman, B.; Ben-Zvi, H.; Atamna, A.; Tau, N.; Mashraki, T.; Nesher, E.; Rahamimov, R. Antibody response to SARS-CoV-2 mRNA vaccine among kidney transplant recipients: A prospective cohort study. Clin. Microbiol. Infect. 2021, 27, 1173.e1-1173.e4. [CrossRef] [PubMed]

13. Anand, S.; Montez-Rath, M.E.; Han, J.; Garcia, P.; Cadden, L.; Hunsader, P.; Kerschmann, R.; Beyer, P.; Dittrich, M.; Block, G.A.; et al. Antibody Response to COVID-19 Vaccination in Patients Receiving Dialysis. J. Am. Soc. Nephrol. 2021, 32, 2435-2438. [CrossRef]

14. Kaiser, R.A.; Haller, M.C.; Apfalter, P.; Kerschner, H.; Cejka, D. Comparison of BNT162b2 (Pfizer-BioNtech) and mRNA-1273 (Moderna) SARS-CoV-2 mRNA vaccine immunogenicity in dialysis patients. Kidney Int. 2021, 100, 697-698. [CrossRef]

15. Van Praet, J.; Reynders, M.; de Bacquer, D.; Viaene, L.; Schoutteten, M.; Caluwé, R.; Doubel, P.; Heylen, L.; De Bel, A.V.; Van Vlem, B.; et al. Predictors and Dynamics of the Humoral and Cellular Immune Response to SARS-CoV-2 mRNA Vaccines in Hemodialysis Patients: A Multicenter Observational Study. J. Am. Soc. Nephrol. 2021, 32, 3208-3220. [CrossRef]

16. Stumpf, J.; Siepmann, T.; Lindner, T.; Karger, C.; Schwöbel, J.; Anders, L.; Faulhaber-Walter, R.; Schewe, J.; Martin, H.; Schirutschke, H.; et al. Humoral and cellular immunity to SARS-CoV-2 vaccination in renal transplant versus dialysis patients: A prospective, multicenter observational study using mRNA-1273 or BNT162b2 mRNA vaccine. Lancet Reg. Health Eur. 2021, 9, 100178. [CrossRef]

17. Dębska-Ślizień, A.; Ślizień, Z.; Muchlado, M.; Kubanek, A.; Piotrowska, M.; Dąbrowska, M.; Tarasewicz, A.; Chamienia, A.; Biedunkiewicz, B.; Renke, M.; et al. Predictors of Humoral Response to mRNA COVID19 Vaccines in Kidney Transplant Recipients: A Longitudinal Study-The COViNEPH Project. Vaccines 2021, 9, 1165. [CrossRef]

18. Kantauskaite, M.; Müller, L.; Kolb, T.; Fischer, S.; Hillebrandt, J.; Ivens, K.; Andree, M.; Luedde, T.; Orth, H.M.; Adams, O.; et al Intensity of mycophenolate mofetil treatment is associated with an impaired immune response to SARS-CoV-2 vaccination in kidney transplant recipients. Am. J. Transplant. 2021, 1-6. [CrossRef]

19. Chavarot, N.; Ouedrani, A.; Marion, O.; Leruez-Ville, M.; Vilain, E.; Baaziz, M.; Del Bello, A.; Burger, C.; Sberro-Soussan, R.; Martinez, F; ; et al. Poor Anti-SARS-CoV-2 Humoral and T-cell Responses After 2 Injections of mRNA Vaccine in Kidney Transplant Recipients Treated with Belatacept. Transplantation 2021, 105, e94-e95. [CrossRef] [PubMed]

20. Terrec, F.; Jouve, T.; Malvezzi, P.; Janbon, B.; Naciri Bennani, H.; Rostaing, L.; Noble, J. Belatacept Use after Kidney Transplantation and Its Effects on Risk of Infection and COVID-19 Vaccine Response. J. Clin. Med. 2021, 10, 5159. [CrossRef] [PubMed]

21. Moor, M.B.; Suter-Riniker, F.; Horn, M.P.; Aeberli, D.; Amsler, J.; Möller, B.; Njue, L.M.; Medri, C.; Angelillo-Scherrer, A.; Borradori, L.; et al. Humoral and cellular responses to mRNA vaccines against SARS-CoV-2 in patients with a history of CD20 B-celldepleting therapy (RituxiVac): An investigator-initiated, single-centre, open-label study. Lancet Rheumatol. 2021, 3, e789-e797. [CrossRef]

22. Jager, K.J.; Kramer, A.; Chesnaye, N.C.; Couchoud, C.; Sánchez-Álvarez, J.E.; Garneata, L.; Collart, F.; Hemmelder, M.H.; Ambuehl, P.; Kerschbaum, J.; et al. Results from the ERA-EDTA Registry indicate a high mortality due to COVID-19 in dialysis patients and kidney transplant recipients across Europe. Kidney Int. 2020, 98, 1540-1548. [CrossRef]

23. Williamson, E.J.; Walker, A.J.; Bhaskaran, K.; Bacon, S.; Bates, C.; Morton, C.E.; Curtis, H.J.; Mehrkar, A.; Evans, D.; Inglesby, P.; et al. Factors associated with COVID-19-related death using OpenSAFELY. Nature 2020, 584, 430-436. [CrossRef]

24. Gansevoort, R.T.; Hilbrands, L.B. CKD is a key risk factor for COVID-19 mortality. Nat. Rev. Nephrol. 2020, 16, 705-706. [CrossRef] [PubMed]

25. Chen, J.-J.; Lee, T.H.; Tian, Y.-C.; Lee, C.-C.; Fan, P.-C.; Chang, C.-H. Immunogenicity Rates after SARS-CoV-2 Vaccination in People with End-stage Kidney Disease: A Systematic Review and Meta-analysis. JAMA Netw. Open 2021, 4, e2131749. [CrossRef]

26. Grupper, A.; Katchman, E.; Ben-Yehoyada, M.; Rabinowich, L.; Schwartz, D.; Schwartz, I.F.; Shashar, M.; Halperin, T.; Turner, D.; Goykhman, Y.; et al. Kidney transplant recipients vaccinated before transplantation maintain superior humoral response to SARS-CoV-2 vaccine. Clin. Transplant. 2021, 35, e14478. [CrossRef] 
27. Blanchard-Rohner, G.; Enriquez, N.; Lemaître, B.; Cadau, G.; Combescure, C.; Giostra, E.; Hadaya, K.; Meyer, P.; Gasche-Soccal, P.M.; Berney, T.; et al. Usefulness of a systematic approach at listing for vaccine prevention in solid organ transplant candidates. Am. J. Transplant. 2019, 19, 512-521. [CrossRef] [PubMed]

28. Kamar, N.; Abravanel, F.; Marion, O.; Couat, C.; Izopet, J.; Del Bello, A. Three Doses of an mRNA Covid-19 Vaccine in Solid-Organ Transplant Recipients. N. Engl. J. Med. 2021, 385, 661-662. [CrossRef]

29. Westhoff, T.H.; Seibert, F.S.; Anft, M.; Blazquez-Navarro, A.; Skrzypczyk, S.; Zgoura, P.; Meister, T.L.; Pfaender, S.; Stumpf, J.; Hugo, C.; et al. A third vaccine dose substantially improves humoral and cellular SARS-CoV-2 immunity in renal transplant recipients with primary humoral nonresponse. Kidney Int. 2021, 100, 1135-1136. [CrossRef]

30. Benotmane, I.; Gautier, G.; Perrin, P.; Olagne, J.; Cognard, N.; Fafi-Kremer, S.; Caillard, S. Antibody Response After a Third Dose of the mRNA-1273 SARS-CoV-2 Vaccine in Kidney Transplant Recipients with Minimal Serologic Response to 2 Doses. JAMA 2021, 326, 1063-1065. [CrossRef]

31. Masset, C.; Kerleau, C.; Garandeau, C.; Ville, S.; Cantarovich, D.; Hourmant, M.; Kervella, D.; Houzet, A.; Guillot-Gueguen, C.; Guihard, I.; et al. A third injection of the BNT162b2 mRNA COVID-19 vaccine in kidney transplant recipients improves the humoral immune response. Kidney Int. 2021, 100, 1132-1135. [CrossRef] [PubMed]

32. Bensouna, I.; Caudwell, V.; Kubab, S.; Acquaviva, S.; Pardon, A.; Vittoz, N.; Dogan-Firat, B.; Hanafi, L.; Faucon, A.L.; Housset, P. SARS-CoV-2 Antibody Response After a Third Dose of the BNT162b2 Vaccine in Patients Receiving Maintenance Hemodialysis or Peritoneal Dialysis. Am. J. Kidney Dis. 2021; in press.

33. Dekervel, M.; Henry, N.; Torreggiani, M.; Pouteau, L.-M.; Imiela, J.-P.; Mellaza, C.; Garnier, A.S.; Dujardin, A.; Asfar, M.; Ducancelle, A.; et al. Humoral response to a third injection of BNT162b2 vaccine in patients on maintenance haemodialysis. Clin. Kidney J. 2021, 14, 2349-2355. [CrossRef] [PubMed]

34. Alejo, J.L.; Mitchell, J.; Chiang, T.P.-Y.; Abedon, A.T.; Boyarsky, B.J.; Avery, R.K.; Tobian, A.A.R.; Levan, M.L.; Massie, A.B.; Garonzik-Wang, J.M.; et al. Antibody Response to a Fourth Dose of a SARS-CoV-2 Vaccine in Solid Organ Transplant Recipients: A Case Series. Transplantation 2021, 105, e280. [CrossRef] [PubMed]

35. Sanders, J.-S.F.; Bemelman, F.J.; Messchendorp, A.L.; Baan, C.C.; van Baarle, D.; van Binnendijk, R.; Diavatopoulos, D.A.; Froelke, S.C.; Geers, D.; GeurtsvanKessel, C.H.; et al. The RECOVAC Immune-response Study: The Immunogenicity, Tolerability, and Safety of COVID-19 Vaccination in Patients with Chronic Kidney Disease, on Dialysis, or Living with a Kidney Transplant. Transplantation, 2021; in press.

36. Quiroga, B.; Soler, M.J.; Ortiz, A.; Vaquera, S.M.; Mantecón, C.J.J.; Useche, G.; Sánchez Márquez, M.G.; Carnerero, M.; Jaldo Rodríguez, M.-T.; Ramos, P.M.; et al. Safety and immediate humoral response of COVID-19 vaccines in chronic kidney disease patients: The SENCOVAC study. Nephrol. Dial. Transplant. 2021; in press.

37. Thieme, C.J.; Blazquez-Navarro, A.; Safi, L.; Kaliszczyk, S.; Paniskaki, K.; Neumann, I.E.; Schmidt, K.; Stockhausen, M.; Hoerstrup, J.; Cinkilic, O.; et al. Impaired Humoral but Substantial Cellular Immune Response to Variants of Concern B1.1.7 and B.1.351 in Hemodialysis Patients after Vaccination with BNT162b2. J. Am. Soc. Nephrol. 2021, 32, 2725-2727. [CrossRef]

38. Hall, V.G.; Ferreira, V.H.; Ierullo, M.; Ku, T.; Marinelli, T.; Majchrzak-Kita, B.; Yousuf, A.; Kulasingam, V.; Humar, A.; Kumar, D. Humoral and cellular immune response and safety of two-dose SARS-CoV-2 mRNA-1273 vaccine in solid organ transplant recipients. Am. J. Transplant. 2021, 12, 3980-3989. [CrossRef]

39. Pedersen, R.M.; Bang, L.L.; Tornby, D.S.; Kierkegaard, H.; Nilsson, A.C.; Johansen, I.S.; Bistrup, C.; Jensen, T.G.; Justesen, U.S.; Andersen, T.E. The SARS-CoV-2-neutralizing capacity of kidney transplant recipients 4 weeks after receiving a second dose of the BNT162b2 vaccine. Kidney Int. 2021, 100, 1129-1131. [CrossRef]

40. Hod, T.; Ben-David, A.; Olmer, L.; Levy, I.; Ghinea, R.; Mor, E.; Lustig, Y.; Rahav, G. Humoral Response of Renal Transplant Recipients to the BNT162b2 SARS-CoV-2 mRNA Vaccine Using Both RBD IgG and Neutralizing Antibodies. Transplantation 2021, 105, e234-e243. [CrossRef]

41. Connolly, C.; Koenig, D.; Ravi, S.; Azar, A.; Kant, S.; Dalal, M.; Duchen, J.; Seo, P.; Antiochos, B.; Paik, J.P.; et al. Correspondence on "SARS-CoV-2 vaccination in rituximab-treated patients: Evidence for impaired humoral but inducible cellular immune response" by Bonelli et al. Ann. Rheum. Dis. 2021, 80, e164. [CrossRef] [PubMed]

42. Kronbichler, A.; Geetha, D.; Smith, R.M.; Egan, A.C.; Bajema, I.M.; Schönemarck, U.; Mahr, A.; Anders, H.J.; Bruchfeld, A.; Cid, M.C.; et al. The COIVD-19 pandemic and ANCA-associated vasculitis-Reports from the EUVAS meeting and EUVAS education forum. Autoimmun. Rev. 2021, 20, 102986. [CrossRef] [PubMed]

43. Harris, R.J.; Hall, J.A.; Zaidi, A.; Andrews, N.J.; Dunbar, J.K.; Dabrera, G. Effect of vaccination on household transmission of SARS-CoV-2 in England. N. Engl. J. Med. 2021, 385, 759-760. [CrossRef] [PubMed] 